\title{
EXPLORING CROSS-CULTURAL DIFFERENCES IN USAGE OF MOBILE PHONES AMONG UNIVERSITY STUDENTS IN US AND INDIA
}

\author{
* Radhika Arora
}

\begin{abstract}
:
The importance of the mobile phone is evidenced by predictions that there will be 1.76 billion smartphone users worldwide at the start of 2015. A country that is spearheading this movement toward the digital era is India.Today mobiles are used by 75\% of the people around the world. It has become an integral part of everybody's daily life. This study investigates usage patterns of, and attitude about, cell phones among university students in a mature market such as (United States) and a rapidly growing new market such as (India) by surveying students in each country.

For India, students between the ages of 21 - 25 years were surveyed from Presidency College MBA students and for the United States, the sample was collected by internet surveys done at UCLA students of the age group of 19-25 years during Sep-Dec 2015.

Key findings from the study include similarities in the usage of phones to communicate with others and in the perception of mobile phone usage in public settings, and differences in the use of text messaging popular apps and mobile phone conduct while driving and in public places such as restaurants and hospitals. For India, students between the age of 21-25 years were surveyed and for the United States, the sample was collected by internet surveys done at UCLA students of the same age group. Overall these results suggest that students in India use mobile phones differently from their American counterparts. The findings also showed that there is hardly any gender difference in usage patterns and preference with regards to mobile phones.
\end{abstract}

Keywords: mobile, culture, usage patterns, self-expression, public places

\section{Introduction:}

Asia is the fastest $\square$ growing region, accounting for one of every four phones sold in 2005, a pace that is projected to increase to one of three by 2009 ("Gartner Press Release", 2005). The latest data from March 2006 indicates that India is the fastest growing mobile market in the world with over 5 million new users added per month bringing the total to over 90 million users ("Telecom Regulatory Authority of India press release", 2006). However this represents only about $8 \%$ of India's estimated total mid02005 population ("Population Reference Bureau Statistics", 2006). The corresponding US data from December 2005 shows that there

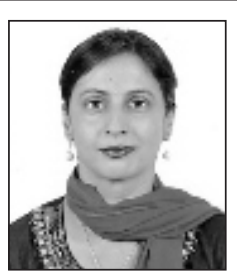

I Author

Radhika Arora

Associate Professor

Centre for Management Studies

Presidency College,

Kempapura, Hebbal, Bangalore - 560064 
are 207 million mobile users in the US ("CTIA SemicAnnual Wireless Industry Survey", 2006).

Today mobile phones are used by threequarters of the world's inhabitants, but the words to describe it and etiquette of how to use it differ starkly across cultures.In the UK, it is called a mobile, in the U.S. cell phone, in Latin America cellular, in Japan keitai (portable), in China shou-ji (hand machine), in Bangladesh muthophone (phone in the palm of your hand), in Sweden nalle (teddy bear), in Israel Pelephone (wonder phone) and in Germany a handy. The most recent Lemelson-MIT Invention Index survey found that $30 \%$ of US adults rate the cell phone as the invention they "hate the most, but can't live without"

This exploratory study investigated usage patterns of, and attitudes about, cell phones among university students in a mature market (United States) and a rapidly growing new market (India) by surveying students in each country. Key findings from the study include similarities in the usage of phones to communicate with others and in the perception of mobile phone usage in public settings and differences in the use of text messaging and opinions regarding driving and mobile phone usage. Overall these results suggest students in India use mobile phones differently from their American counterparts.

The products and services Indian students tend to choose represent their self-image. They are comfortable with technology and most of their socializing take place online. Their mobile devices are a part of their personal selves and a mobile telecommunication service that connects them with the world and people around them is a vital companion to them. Due to their lack of commitments, these young people tend to spend more for their mobile lifestyles. More than $70 \%$ of them cannot do without their phones as they believe it expresses their identity. They also use their mobile devices to communicate in many different ways. For example, in Britain, over $30 \%$ of them use their mobile phones to surf the internet and text their friends. In Asia, the forecast is that these young mobile users will spend over US\$13 billion on data services including mobile TV and surfing the web.

\section{Literature Review}

The cultural background can influence the way technology is perceived, adopted and used. Despite the global nature of the adoption of mobile technologies, there are only a few studies which have investigated the cross $\square$ cultural aspects. An early study conducted by Aoki and Downes (2002) which used focus group (qualitative) and survey (quantitative) to study the usage of cell phones among student. This study suggests these individuals use the devices for a variety of purposes: to help them feel safe, for financial benefits, to manage time efficiently, to keep in touch with friends and family members, et al. This study was conducted in the United States (among students of North East University in Dec 2001) with a sample size of 137 respondents.

The literature review of other studies conducted in this area also shows the significant societal influence that usage of mobile phones has on a culture. For instance, in 1997, James E. Katz, a prominent US researcher studied the social aspects of mobile communication and its possible effects upon people. In his study he identified, several levels of effects of such a technology: namely "firstorder effects," direct effects that are immediately perceived by users; "second-order effects," indirect effects that are "experiences or feelings that people have or may observe in others" (Katz, 1997, p. 235) and "third-order 
effects," the least direct effects that are observed not by users of the technology but by outside observers who study the effects of the technology upon the society in general. Katz listed uncertainty reduction, personal security, and personal efficiency, as the first-order effects of wireless communications on personal lives; tighter coupling of domestic production, information immediacy, and being in contact with the second-order effects; and social interaction, social control, and innovative uses or unanticipated usage as the third-order effects. In another study by Palen (2002), the difference between the initial intention and the actual nature of cell phone was studied. Initially, the perception about the use of a cellphone in public places was overwhelmingly negative. However, they noted that new users over a period of time became more accepting of the use of mobile phones in public places. Palen (2002) found that people initially adopted cell phones for safety/security and "business" or job-related reasons, instead of social reasons but found that later on the use of their cell phones for sociable interactions had become very important over a period of time.

These interactions may not even be the traditional voice-based interaction Palen [5] discusses how mobile phones allow individuals to maintain connectedness and expand the scope of their activities beyond what was achievable without the technology. However, this accessibility involves tradeoffs - the social unacceptability of use at inappropriate times versus the consequences of missing a call when the phone is turned off. In another study, Ling and Yttri (1999), studied in particular teenage cell phone users through a series of focus group interviews, indicated the adoption of cell phones resulted in new forms of interaction called "micro-coordination and hypercoordination." In Japan, teenagers are supposed to be the driving force in the most use of cell phones (Mitusoaka et al., 2001). It has been estimated that mobile phone devices will out number televisions and personal computers in a few years. There is another study in Sweden which reiterates the difference between users in different countries. (Baron, 2009)

The review of literature also shows that the usage of mobile phone technology has a significant societal influence. The connected nature of the technology is shaping attitudinal changes regarding public and private space of mobile phone usage. There are cross-cultural differences in how customers respond to marketing communication (Svovodoba, 2013)

Participants of focus groups in Norway stated that cell phones should not be used in airports, stores, meetings, on trains and buses, at certain social functions, and in theaters, with the most serious offense involving the use of a mobile phone in a restaurant. A study by Palen, Salzman and Youngs [6] (2000) showed that a person's attitude towards public cell phone use changes (becomes more accepting) as they use cell phones more. Their study has studied the perception of mobile phone usage in the public with respect to new mobile users over a period of six weeks after acquisition of phones. Using interviews and voiceDmail, their study noted that patterns of mobile phone usage varied over time and there was a significant deviation between the user $\square$ predicted usage to their actual usage. Palen [5] predicted that as an adoption of cell phones increases, people will be less concerned about appropriate use, but will still call for "cell-free" zones. (Like hospital, schools etc.)

\section{Significance of the Study}

The importance of this area and the study of the behavioral characteristics involved are being just realized. However, relatively few studies are available which look at this issue from a 
cross cultural perspective, especially the youth segment of the mobile phone user market. Most of the previous studies were conducted in European countries and the United States. A cross $\square$ cultural study between users in India and United States will enable a comparative perspective into a mature and developing market.

\section{Objectives of the Study}

- To understand in what ways are cell phones used in different cultures and different social settings?

- To understand the perception regarding acceptable use of cell phones in social settings across cultures

- To understand the Safety Issues of using a cellphone while driving in both cultures

- To understand the acceptable and actual use of cellphones among the US students and Indian university students

\section{Research Design}

The present study has tried to use the study conducted by Aoki and Downes (2002) as a framework and extend the previous research to include a cross $\square$ cultural comparison of university students in the United States and India. Knowing the intrinsic motivation for adopting technology will help us to understand why a technology is used a certain way by a particular group of people (culture). The behavioral characteristics that include usage data such as length of cell phone usage, typical time of cell phone use, average number of calls received/sent, typical location of cell phone use.

Research Statement: "Cultural Differences exist in usage of mobile phones among university students in US and India

\section{Research Instrument used for Data Collection}

This research is a questionnaireDbased exploratory study to investigate the cross $\square$ cultural usage patterns of mobile phones. The study has used basic demographic, motivational and behavioral characteristics of the respondents who are university students. Motivational questions in the questionnaire were based on findings of focus group interviews conducted by Aoki and Downes (2004). The behavioral questions were based on the sections suggested in the report of Bautsch et al., (2001).

The three behavioral sections defined were usage, safety issues, public perception of mobile phones and socially acceptable usage guidelines or etiquette. Additional questions were based on other relevant research. Shared use was incorporated based on the study of phone borrowing by Castells, Mireia, Qiu, and Sey (2004).

The cross $\square$ cultural perspectives of text messaging and phone usage while driving were based on the study of French and American users by Issac, Nickerson, and Tarasewich (2004).

\section{Scope of the Study}

Participants for the study included students at universities in the United States and India. Only university students between the ages of 18 - 24 years from India and the United States were included in the study. Responses were accepted regardless of fullDtime or part $\square$ time, undergraduate or graduate student who had a reasonable knowledge of the English language.

A nonЊprobability based convenience sampling was used. Thus, the sampling frame comprised of student volunteers from at least one 
university each in India and United States. In both the cases, the selection of the respondents was based on the researchers' acquaintances and student community known to the author.

Respondents were asked to forward the questionnaire to other acquaintances. A request to participate in the survey were mailed out on open student mailing list in the United States to collect data from undergraduate and post graduates students studying at UCLA. In India, the data was collected from MBA students from Presidency College. The survey was closed after receiving a total of 100 responses, 50 each from both the places. A non $\square$ random convenience sampling was used, therefore the respondents are not representative of their populations.

The study was conducted in Sep - Dec 2015 in the city of Bangalore and at UCLA California in the United States. The age group of the respondents was between the ages of $18-26$ years.

\section{Analysis and Discussions}

- Demographic Profile of the Sample:

The analysis for the study used a sample of 100 respondents which included 57 men and 43 women. The majority ( $76 \%$ ) of the respondents from India were male whereas most of the respondents $(62 \%)$ from the United States were female. The average American respondent was 23.6 years old and the average Indian respondent was 22.7 years old.

The frequency and cross $\square$ tabulation of the education level of the respondents show that all the respondents from India were graduate students, mostly from Presidency College. The respondents from the United States were either undergraduate and postgraduate students at UCLA show a more varied education level.
The respondents from the United States had a greater range of ages with a standard deviation of 7.17 compared the standard deviation of 2.27 among the Indian respondents.

- $\quad$ Findings suggest that there are significant differences in use of phone services such as in the use of text messaging and opinions regarding driving and mobile phone usage. Overall these results suggest students in India use mobile phones differently from their American counterparts.

\section{Similarities}

- The majority of respondents (94\% in India and $98 \%$ in the US) indicated that they own the phones they use.

- Most respondents said that they don't share their phone with anyone India (90\%) and USA (92\%) and the minority who do so only share their phones with close family members.(refer to Table 3 )

- When respondents were asked about the reason for acquiring mobile phones, most of the responses indicated the need to use to stay in touch with family and friends, and the need to use in case of emergency or personal safety.

- Across all cultures, the level of tolerance for usage of mobile phones (in public and private spaces) has increased because of the pervasiveness of its use.

\section{Differences}

- Twenty-five percent of students in India indicated use in an emergency as the most important reason for acquiring a mobile phone compared to $40 \%$ students in the United States.

- An interesting result was, $40 \%$ of Indian students choose 'staying in touch with 
parents' as the highest ranked reason for acquiring a mobile phone compared with only $8 \%$ of American students (refer to Table 4)

- Respondents over $80 \%$ have been using a phone for a long time, at least over a year. Only about $6 \%$ from India said that they have had a phone for less than a month, which shows the growing expansion of phone users in India, which is a relatively less mature market than the USA (refer to Table 5)

- The opinion was divided about whether the service plan that they have affects the usage of the mobile phone (refer to Table 6 ). From the table we can see that $50 \%$ answered "Yes" and 42\% answered "No". There is also no significant difference across both the countries in this case

- $80 \%$ percent of US respondents replied that they sometimes make and receive calls while driving compared to $40 \%$ of Indian respondents. (refer table 8 ). 36\% percent of Indian respondents and only $4 \%$ of US respondents said that they never make and receive calls while driving.(refer table 8)

- Another question where the respondents were asked to choose scenarios where they would turn off their phones (refer to table 9). The comments indicated that respondents turn off their phones while traveling in an airplane. $36 \%$ of US respondents said they would turn off their cellphones during a movie while none in India $(0 \%)$ said they would. This is a distinct difference in culture and etiquette

- Respondents from both India and the United States indicated that they use phones more in the evening than any other time of the day $(76 \%$ and $86 \%$ respectively) (refer to table 10). The least used time of the day was in the morning with only $44 \%$ and $48 \%$ responses from India and the United States.

- For most respondents, their mobile phone was their primary phone $76 \%$ in India and $68 \%$ in the USA (refer to table 11). It is interesting to note that this number is more in India than in the US, showing the level of mobile penetration in India in recent times.

- Most respondents are happy with their service provider $72 \%$ in India and $76 \%$ in the USA (refer to table 12). But this does not have any impact on their usage pattern or usage level.

- $\quad 80 \%$ percent of US respondents replied that they sometimes make and receive calls while driving compared to $40 \%$ of Indian respondents. (refer to table 13). This may be because the sample was collected on a university campus where there is not a lot of driving involved

- $30 \%$ percent of Indian respondents and only $10 \%$ of US respondents said that they never make and receive calls while driving.(refer table 14)

- $36 \%$ of Indian respondents compared to only $18 \%$ of US respondents strongly agreed that talking on the phone while driving is dangerous and should be banned by law(refer table 16).

- Respondents were asked if they were ever annoyed by someone using a mobile phone. $90 \%$ of the US respondents and $62 \%$ of Indian respondents replied in the affirmative (refer Table 18).

- Most respondents don't want cell phones to be banned in public places. Cell phones are today indispensable even across cultures 
- $\quad 32 \%$ Indian respondents and $24 \%$ of US respondents strongly agreed to only allowing discreet or quiet talking on phones in public places(refer Table 20).A further $32 \%$ each of respondents from both countries agreed to the statement.

- $\quad 57 \%$ disagreed that you can talk loudly in public places (66\% Indian respondents and 48\% US respondents(refer Table 21). This shows that most respondents wanted a particular etiquette to be followed with respect to use of cell phones in public places.

\section{Conclusion}

Overall, this study shows that there are significant cultural differences in the perception of mobile phone usage in public settings, and differences were found in the use of text messaging, pattern of usage of the mobile phone instrument, mobile phone conduct while driving and overall usage in India (a developing market) and in US (a mature cell-phone market).

However, these differences, are going to reduce because of the increasing globalization and easy access to newer technologies. Technological advances will transcend the cultural differences and more. For example, even though this survey shows that driving and talking on the phone is less popular in India, with increasing technologies like SIRI and hands-free devices, the younger generation feel more comfortable using their mobile phone while driving. For instance, there is now increasing tolerance towards using a mobile phone in public and respondents of both cultures don't want cell phones to be banned in public places. In the current scenario, the gap in mobile technology across developed and developing countries is closing. Today, cell phones are indispensable even across cultures and gap in usage patterns and etiquette is blurring.

\section{Managerial Implications.}

Mobile phones are redefining and blurring the line between public and private spaces.With more Open Plan Office designs mobile phone etiquette may be required to be taught as soft skills to new entrants to respect others' spaceespecially with cross-cultural factors becoming more relevant with the globalization of business.

It is clear that globally the young consumer is a very important market for mobile telephone firms. Therefore firms in this industry must focus on this generation as a key objective for growth and sustainable competitive advantage. This research may serve as useful input to telecommunication companies, researchers (information science, social communication, etc.) and media futurists. This study may help information architects in designing interfaces to meet the unique needs of the particular market. For instance, the results of this research can be used to predict the mobile commerce (m-commerce) behavior of customers and what m-commerce services to provide them with. This is already becoming evident in Indian market where m-commerce and "apps" are ruling the day. If products are linked to the customer location, the results may also provide some help in identifying the types of products that are most likely to be positively received by customers through a mobile medium. Cell phones have become a "subculture" in all realms of our life, both public and private, blurring the boundary between work and private life.

\section{Limitations and Further Research}

The limitation of this study is that the study was done in a specific age group and in both places in university campuses. This may not be 
a representative sample from other areas and across different age categories. The study can be scaled up to retrieve data from other countries and possibly venture into the cultural differences between urban mobile phone users versus rural phone users in India. Also, another area of focus can be on the use of mobile phones in the business area of m-commerce. This aspect has not been explored in this study.

\section{Bibliography}

Aoki, K., Downes, E. J. (2004). “An analysis of young people's use of and attitudes toward cell phones". Telematics and Informatics, Vol 20 (4), pg 349प364

Babbie, E. (2000). The Practice of Social Research 9thedition, Belmont, CA: Wadsworth Thomson Learning

Back, M.D., Stopfer, J.M., Vazire, S., Gaddis, S., Schmukle, S.C., Egloff, B., Gosling, S.D.,2010. Facebook profiles reflect actual personality, not self-idealization. Psychological Science. 21,372-374.

Barker, V., 2009. Older adolescents' motivations for social network site use: The influence of gender, group identity, and collective self-esteem. CyberPsychology\& Behavior.12(2),209-213.

Baron, N.S., 2009. Cross- cultural patterns in mobile phone use: Public space and reachability in Sweden, the US, and Japan.

Baron, N.S., 2004. See you online: Gender issues in college student use of instant messaging.Journal of Language and Social Psychology. 23,397-423.

Bautsch, H., Granger, J., Karnjate, T., Kahn, F., Leveston, Z., Niehus, G., et al. (2001). An investigation of mobile phone use: A socioDtechnical approach. SocioDtechnical Systems in Industry, Summer Session 2001.
Department of Industrial Engineering. University of WisconsinपMadison. Retrieved $\mathrm{O}$ c t o b e r $10,2 \begin{array}{llllllll} & 0 & 0 & 5 & \mathrm{fr} & \mathrm{o} & \mathrm{m}\end{array}$ http://homepages.cae.wisc.edu/ granger/IE449/ IE449_0108.pdf

Brown, N. Green \& R. Harper (Editors.) Wireless World: Social and Interactional Aspects of the Mobile Age. Godalming and H i ed leburg: S pringer Verlag, pp.990115.http://edition.cnn.com/2012/09/27/t ech/mobile-culture-usage/

Carlson, P. J., Kahn, B. K., and Rowe, F. (1999). Organizational Impacts of New communication Technology: A Comparison of Cellular Phone Adoption in France and the United States. Journal of Global Information Management, 7(3), $19 \square 29$.

Carrie, La Farle, Muralidharan, Sidharth. (2015). How Culture Influences the "Social" in Social Media: Socializing and Advertising on Smartphones in India and the United States.Cyberpsychology, Behavior, and Social Networking.June 2015, Vol. 18, No. 6: 356-360

Castells, M., Mireia, F., Qiu, J., Sey, A. (2004). The Mobile Communication Society. Research report for the International Workshop on Wireless Communication Policies and Prospects: A Global Perspective. Retrieved $\begin{array}{lllll}\mathrm{O} \text { c t o b e r } & 27, & 2005\end{array}$ fromhttp://annenberg.usc.edu/international_co mmunication/WirelessWorkshop/MCS.pdf

Cooper, G. (2002). Who's watching whom? Monitoring and accountability in mobile relations. In B. Brown, N. Green, and R. Harper, (Eds.) Wireless world: social and interactional aspects of the mobile age.

Emery, T. Cell Phone Most Hated, Needed Innovation. BizReport, January 21, 2004, available at: http://www.bizreport.com/ article.php?art_id=5980. 
Gartner Press Release (2005). Gartner Says Mobile Phone Sales Will Exceed One Billion in 2009. Retrieved April 11, 2006 from http://www.gartner.com/press_releases/asset_1 32473_11.html

Hofvenschiold, E. (2003). Determining Cultural Issues in Attitude to and Use of Mobile Phones. Proceedings of the German Chapter of Usability Professionals 2003, 1710174

Issac, H. Nickerson, R., Tarasewich, P., (2004). Cell Phone Use in Social Settings: Preliminary Results from a Study in the United States and France. Proceedings of the DSI 2004 Annual Meeting. Retrieved October 3, 2005 from http://www.ccs.neu.edu/home/tarase/

J.A. Costa and G. Bamossy (eds.), Marketing in the Multicultural World, 26067, SAGE Publications.

London: Springer. CTIA SemicAnnual Wireless Industry Survey. (2006) Washington DC: CTIADThe Wireless Association. Retrieved April 11, 2006 from http://www.ctia.org/research_statistics/index.cf $\mathrm{m} / \mathrm{AID} / 10030$

Ling, R., Yttri, B., 1999. Nobody sits at home and waits for the telephone to ring: micro and hyper-coordination through the use of the mobile telephone. Retrieved May 13, 2002, from <http://www.telenor.no/fou/prosjekter/ Fremtidens_Brukere/Rich/Nobody $\% 20$ sits $\% 20$ at $\% 20$ home $\% 20$ and $\% 20$ waits.doc $>$.

Ling, R. One Can Talk About Common Manners!: The Use of Mobile Telephones in Inappropriate Situations. In Haddon, L. (ed.) Themes in Mobile Telephony, Final Report of the COST 248 Home and Work Group, 1997.

McGuigan, J. (2005). Towards a Sociology of the Mobile Phone. Human Technology Vol
1(1) Retrieved $10 / 28 / 2005$ from http://www.humantechnology.jyu.fi

Motorola (2006). Towards the next billion subscribers: Motorola delivers on seamless mobility vision. Retrieved April 11, 2006 fromhttp://www.motorola.com/mediacenter/ne ws/detail/0,,6405_6355_23,00.html\#fn1

Palen, L. Mobile Telephony in a Connected Life . Communications of the ACM, 2002, 45(3), 78-82.

Palen, L., Salzman, M., and Youngs, E. Going Wireless: Behavior and Practice of New Mobile Phone Users. Proceedings of the Conference on Computer Supported Cooperative Work (CSCW '00), Philadelphia, PA. 2000, 201-210.

Plant, S., 2001. On the mobile: the effects of mobile telephones on social and individual life. Available from $<$ http://www.motorola.com/ mot/documents/0,1028,333,00.pdf $>$.

Population Reference Bureau Country Statistics. (2006). Washington DC: Population Reference Bureau. Retrieved 4/11/2006.

Puro, J., 2002. Finland: a mobile culture. In: Katz, J., Aakhus, M. (Eds.), Perpetual Contact: MobileCommunication, Private Talk, Public Performance. Cambridge University Press, New York, pp. 19-29

Rheingold, H. (2002). Smart Mobs: The Next Social Revolution. Cambridge, MA: Perseus Books/Basic Books.

Shalit, R. Techno-Etiquette for the Mobile Age. impulse, December 2003, available at www.cooltown.com/mpulse/1203-etiquette.asp.

Telecom Regulatory Authority of India (2006). Press release dated 4/10/2006 (no. 36/2006) New Delhi: Telecom Regulatory Authority of India. Retrieved 4/11/2006 from http://www.trai.gov.in/pr10apr06.pdf 
Townsend, A.M. ( 2002$)$. Mobile communications in the twenty $D$ first century city. In B. Brown, N. Green and R. Harper (eds.), Wireless World: Social and Interactional Aspects of the Mobile Age,(2002), 62-77, springer
Venkatesh, A.(1995). Ethnoconsumerism: A New Paradigm to Study Cultural and Cross $\mathrm{C}$ Cultural Consumer Behavior.

Weilenmann, A., \& Larsson, C. (2001). Local Use and Sharing of Mobile Phones. pp 92 107.

Data Analysis for "Exploring Cross Cultural Differences in usage of Mobile Phones among University Students in US and India"

Detailed demographic distribution of gender, age and education levels are shown below (DATA TABLES)

Table 1: Gender

\begin{tabular}{|l|c|c|}
\hline Country & Male (percent) & Female (percent) \\
\hline India & $38(76 \%)$ & $12(24 \%)$ \\
\hline United States & $19(38 \%)$ & $31(62 \%)$ \\
\hline Total (Percent) & $57(57 \%)$ & $43(43 \%)$ \\
\hline
\end{tabular}

Table 2: Age

\begin{tabular}{|l|c|c|c|}
\hline Statistic & USA & INDIA & Total \\
\hline Average & 23.7 & 28.68 & 26.19 \\
\hline Standard Deviation & 2.27 & 7.17 & 5.87 \\
\hline Minimum & 19 & 22 & 19 \\
\hline Maximum & 28 & 59 & 59 \\
\hline
\end{tabular}


Table 3: Shared use of phone (Shared usage)

\begin{tabular}{|l|c|c|c|}
\hline Shared use of phone & India & USA & Total \\
\hline I do not share my mobile phone with anyone. & $45(90 \%)$ & $46(92 \%)$ & $91(91 \%)$ \\
\hline I share my mobile phone. & $4(8 \%)$ & $2(4 \%)$ & $6(6 \%)$ \\
\hline No answer & $1(2 \%)$ & $2(4 \%)$ & $3(3 \%)$ \\
\hline Total & $50(100 \%)$ & $50(100 \%)$ & $100(100 \%)$ \\
\hline
\end{tabular}

Table 4: Highest ranked reason for acquiring a mobile phone

\begin{tabular}{|l|c|c|c|}
\hline $\begin{array}{l}\text { Highest ranked reason for } \\
\text { acquiring a mobile phone }\end{array}$ & India & USA & Total \\
\hline Emergencyuse orpersonal & $14(28 \%)$ & $20(40 \%)$ & $34(34 \%)$ \\
\hline To keep intouch with friends & $14(28 \%)$ & $13(26 \%)$ & $27(27 \%)$ \\
\hline To keep intouch with parents & $20(40 \%)$ & $4(8 \%)$ & $24(24 \%)$ \\
\hline Everyone I know had a mobile & $2(4 \%)$ & $1(2 \%)$ & $3(3 \%)$ \\
\hline Business Reasons & $0(0 \%)$ & $1(2 \%)$ & $1(1 \%)$ \\
\hline If offers good Value & $0(0 \%)$ & $5(10 \%)$ & $5(5 \%)$ \\
\hline Other & $0(0 \%)$ & $6(12 \%)$ & $6(6 \%)$ \\
\hline Total & $50(100 \%)$ & $50(100 \%)$ & $100(100 \%)$ \\
\hline
\end{tabular}

Table 5: Duration of usage / experience

\begin{tabular}{|l|c|c|c|}
\hline $\begin{array}{l}\text { Duration of usage / } \\
\text { experience }\end{array}$ & India & USA & Total \\
\hline Less than 1 month & $3(6 \%)$ & $0(0 \%)$ & $3(3 \%)$ \\
\hline $\begin{array}{l}\text { More than 1 month but less } \\
\text { than 3 months }\end{array}$ & $0(0 \%)$ & $0(0 \%)$ & $0(0 \%)$ \\
\hline $\begin{array}{l}\text { More than 3 months but less } \\
\text { than 6 months }\end{array}$ & $0(0 \%)$ & $0(0 \%)$ & $0(0 \%)$ \\
\hline $\begin{array}{l}\text { More than 6 months but less } \\
\text { than 1 year }\end{array}$ & $3(6 \%)$ & $4(8 \%)$ & $7(7 \%)$ \\
\hline More than 1 year & $42(84 \%)$ & $43(86 \%)$ & $85(85 \%)$ \\
\hline No answer & $2(4 \%)$ & $3(6 \%)$ & $5(5 \%)$ \\
\hline Total & $50(100 \%)$ & $50(100 \%)$ & $100(100 \%)$ \\
\hline
\end{tabular}

Table 6: Does service plan affect usage?

\begin{tabular}{|l|c|c|c|}
\hline $\begin{array}{l}\text { Service plan affects } \\
\text { your usage of phone }\end{array}$ & India & USA & Total \\
\hline Yes & $25(50 \%)$ & $25(50 \%)$ & $50(50 \%)$ \\
\hline No & $19(38 \%)$ & $23(46 \%)$ & $42(42 \%)$ \\
\hline No Answer & $6(12 \%)$ & $2(4 \%)$ & $8(8 \%)$ \\
\hline Total & $50(100 \%)$ & $50(100 \%)$ & $100(100 \%)$ \\
\hline
\end{tabular}


Table 7: Scenarios where phone is kept mute / vibration mode

\begin{tabular}{|l|c|c|c|}
\hline \multicolumn{3}{|l|}{ Table 7: Scenarios where phone is kept mute/vibration mode } & Total \\
\hline $\begin{array}{l}\text { Scenarios when phone is in mute or } \\
\text { vibration mode }\end{array}$ & India & USA & \\
\hline While in class & $35(70 \%)$ & $33(66 \%)$ & $68(68 \%)$ \\
\hline While at work & $23(46 \%)$ & $27(54 \%)$ & $50(50 \%)$ \\
\hline At a movie or a concert & $35(70 \%)$ & $30(60 \%)$ & $65(65 \%)$ \\
\hline While driving & $8(16 \%)$ & $8(4 \%)$ & $16(16 \%)$ \\
\hline While sleeping & $9(18 \%)$ & $4(8 \%)$ & $13(13 \%)$ \\
\hline Other & $8(16 \%)$ & $11(22 \%)$ & $19(19 \%)$ \\
\hline Phone is never in mute or vibration mode & $3(6 \%)$ & $3(6 \%)$ & $6(6 \%)$ \\
\hline
\end{tabular}

NOTE: more than one option has been chosen by the respondents

Table 8: Mobile phone usage while driving

\begin{tabular}{|l|c|c|c|}
\hline Mobile phone usage while driving & India & USA & Total \\
\hline Not Applicable & $9(18 \%)$ & $3(6 \%)$ & $12(12 \%)$ \\
\hline Never & $18(36 \%)$ & $2(4 \%)$ & $20(20 \%)$ \\
\hline Sometimes & $20(40 \%)$ & $40(80 \%)$ & $60(60 \%)$ \\
\hline Always & $1(2 \%)$ & $3(6 \%)$ & $4(4 \%)$ \\
\hline No answer & $2(4 \%)$ & $2(4 \%)$ & $4(4 \%)$ \\
\hline Total & $50(100 \%)$ & $50(100 \%)$ & $100(100 \%)$ \\
\hline
\end{tabular}

Table 9: Scenarios when phone is turned off

\begin{tabular}{|l|c|c|}
\hline $\begin{array}{l}\text { Scenarios when phone is turned } \\
\text { off }\end{array}$ & India & USA \\
\hline My phone is never switched off & $34(68 \%)$ & $38 \%$ \\
\hline While in class & $5(10 \%)$ & $30 \%$ \\
\hline While at work & $0(0 \%)$ & $18 \%$ \\
\hline At a movie or a concert & $0(0 \%)$ & $36 \%$ \\
\hline While driving & $1(2 \%)$ & $2 \%$ \\
\hline While sleeping & $4(8 \%)$ & $20 \%$ \\
\hline Other & $6(12 \%)$ & $20 \%$ \\
\hline Total & $50(100 \%)$ & $50(100 \%)$ \\
\hline
\end{tabular}

Table 10: Commonly reported time of phone use

\begin{tabular}{|l|c|c|}
\hline $\begin{array}{l}\text { Is your mobile phone your } \\
\text { primary phone? }\end{array}$ & India & USA \\
\hline Yes & $76 \%$ & $68 \%$ \\
\hline No & $16 \%$ & $28 \%$ \\
\hline No answer & $8 \%$ & $4 \%$ \\
\hline Other & $0 \%$ & $0 \%$ \\
\hline
\end{tabular}


Table 11: Mobile phone as primary phone

\begin{tabular}{|l|c|c|}
\hline Commonly reported time of phone use & India & USA \\
\hline Morning & $22(44 \%)$ & $24(48 \%)$ \\
\hline Afternoon & $29(58 \%)$ & $28(56 \%)$ \\
\hline Evening & $38(76 \%)$ & $43(86 \%)$ \\
\hline Late night & $31(62 \%)$ & $25(50 \%)$ \\
\hline
\end{tabular}

Table 12: Satisfaction with service provider

\begin{tabular}{|l|c|c|}
\hline Satisfaction with service provider & India & USA \\
\hline Yes & $72 \%$ & $76 \%$ \\
\hline No & $18 \%$ & $16 \%$ \\
\hline No answer & $6 \%$ & $4 \%$ \\
\hline Don't know / Other & $4 \%$ & $4 \%$ \\
\hline
\end{tabular}

Table 13: Mobile phone usage while driving

\begin{tabular}{|l|l|l|l|}
\hline Mobile phone usage while driving & India & USA & Total \\
\hline Not Applicable & $9(18 \%)$ & $3(6 \%)$ & $12(12 \%)$ \\
\hline Never & $18(36 \%)$ & $2(4 \%)$ & $20(20 \%)$ \\
\hline Sometimes & $20(40 \%)$ & $40(80 \%)$ & $60(60 \%)$ \\
\hline Always & $1(2 \%)$ & $3(6 \%)$ & $4(4 \%)$ \\
\hline No Answer & $2(4 \%)$ & $2(4 \%)$ & $4(4 \%)$ \\
\hline Total & 50 & 50 & 100 \\
\hline
\end{tabular}

Table 14: Make and receive calls while driving

\begin{tabular}{|l|l|l|c|}
\hline Make and receive calls while driving & India & USA & Total \\
\hline Not Applicable & $9(18 \%)$ & $4(8 \%)$ & 13 \\
\hline Never & $15(30 \%$ & $5(10 \%)$ & 20 \\
\hline Sometimes & $23(46 \%)$ & $35(70 \%)$ & 58 \\
\hline Always & $1(2 \%)$ & $3(6 \%)$ & 4 \\
\hline No Answer & $2(4 \%)$ & $3(6 \%)$ & 5 \\
\hline Total & 50 & 50 & 100 \\
\hline
\end{tabular}

Table 15: Feeling safe while driving and using a mobile phone

\begin{tabular}{|l|l|l|c|}
\hline Feeling safe while driving and using a mobile phone & India & USA & Total \\
\hline Not Applicable & $7(14 \%)$ & $6(12 \%)$ & 13 \\
\hline Never & $22(44 \%)$ & $16(32 \%)$ & 38 \\
\hline Sometimes & $10(20 \%)$ & $23(46 \%)$ & 33 \\
\hline Always & $6(12 \%)$ & $5(10 \%)$ & 11 \\
\hline No Answer & $5(10 \%)$ & $3(6 \%)$ & 8 \\
\hline Total & $50(100 \%)$ & $50(100 \%)$ & 100 \\
\hline
\end{tabular}


Table 16: Talking on phone while driving is dangerous and should be banned by law

\begin{tabular}{|c|c|c|c|}
\hline $\begin{array}{l}\text { Talking on phone while driving is dangerous and } \\
\text { should be banned by law }\end{array}$ & India & USA & Total \\
\hline Strongly Disagree & $(4 \%) 2$ & $(2 \%) \quad 1$ & 3 \\
\hline Disagree & $(6 \%) 3$ & $(26 \%) 13$ & 16 \\
\hline Neutral & $(24 \%) 12$ & $(24 \%) 12$ & 24 \\
\hline Agree & $(26 \%) 13$ & $(26 \%) 13$ & 26 \\
\hline Strongly Agree & $(36 \%) 18$ & $(18 \%) \quad 9$ & 27 \\
\hline No Answer & $(4 \%) 2$ & $(4 \%) \quad 2$ & 4 \\
\hline Total & $(100 \%) 50$ & $(100 \%) 50$ & 100 \\
\hline
\end{tabular}

Table 17: Talking on the phone and driving at the same time is alright

\begin{tabular}{|c|c|c|c|}
\hline $\begin{array}{l}\text { Talking on phone and driving at the same time is } \\
\text { alright be }\end{array}$ & India & USA & Total \\
\hline Strongly Disagree & $(48 \%) 24$ & $(20 \%) 10$ & 34 \\
\hline Disagree & $\begin{array}{l}(22 \%) \\
11\end{array}$ & $(30 \%) 15$ & 26 \\
\hline Neutral & $(6 \%)$ & $(24 \%) 12$ & 15 \\
\hline Agree & $(12 \%) \quad 6$ & $(18 \%) \quad 9$ & 15 \\
\hline Strongly Agree & $(4 \%) \quad 2$ & $(2 \%) \quad 1$ & 3 \\
\hline No Answer & $\begin{array}{ll}(8 \%) & 4\end{array}$ & $\begin{array}{ll}(6 \%) & 3 \\
\end{array}$ & 7 \\
\hline Total & $(100 \%) 50$ & $(100 \%) 50$ & 100 \\
\hline
\end{tabular}

Public and social perception

Table 18: Did someone using a mobile phone ever annoy you?

\begin{tabular}{|c|c|c|c|}
\hline $\begin{array}{l}\text { Someone using a mobile phone ever annoy } \\
\text { you }\end{array}$ & India & USA & Total \\
\hline Not Applicable & $(0 \%)$ & $\begin{array}{ll}(2 \%) & 1 \\
\end{array}$ & 1 \\
\hline No & $\begin{array}{ll}(22 \%) & 11\end{array}$ & $\begin{array}{ll}(8 \%) & 4\end{array}$ & 15 \\
\hline Yes & $\begin{array}{ll}(62 \%) & 31 \\
\end{array}$ & $(90 \%) 45$ & 76 \\
\hline No Answer & $(16 \%) 8$ & $(0 \%) \quad 0$ & 8 \\
\hline Total & 50 & 50 & 100 \\
\hline
\end{tabular}

Table 19: Talking on phones in public places should be banned by law

\begin{tabular}{|c|c|c|c|}
\hline $\begin{array}{l}\text { Talking on phone in Public Places should be banned by } \\
\text { law }\end{array}$ & India & USA & Total \\
\hline Strongly Disagree & $(42 \%) 21$ & $\begin{array}{ll}(46 \%) & 23\end{array}$ & 44 \\
\hline Disagree & $(26 \%) 13$ & $(34 \%) \quad 17$ & 30 \\
\hline Neutral & $\begin{array}{ll}(16 \%) & 8 \\
\end{array}$ & $(14 \%) 7$ & 15 \\
\hline Agree & $(8 \%) \quad 4$ & $(4 \%)$ & 6 \\
\hline Strongly Agree & $\begin{array}{ll}16 \%) & 3 \\
\end{array}$ & $(2 \%)$ & 4 \\
\hline No Answer & $(2 \%)$ & $(0 \%)$ & 1 \\
\hline Total & $(100 \%) 50$ & $(100 \%) 50$ & 100 \\
\hline
\end{tabular}


Table 20: Only talking discreetly or quietly on phones in public places should be allowed

\begin{tabular}{|l|ll|ll|c|}
\hline $\begin{array}{l}\text { Only talking discreetly or quietly on phones in public } \\
\text { places should be allowed }\end{array}$ & India & USA & Total \\
\hline Strongly Disagree & $(6 \%)$ & 3 & $(14 \%)$ & 7 & 10 \\
\hline Disagree & $(12 \%)$ & 6 & $(8 \%)$ & 4 & 10 \\
\hline Neutral & $(16 \%)$ & 8 & $(20 \%)$ & 10 & 18 \\
\hline Agree & $(32 \%)$ & 16 & $(32 \%)$ & 16 & 6 \\
\hline Strongly Agree & $(32 \%)$ & 16 & $(24 \%)$ & 12 & 4 \\
\hline No Answer & $(2 \%)$ & 1 & $(4 \%)$ & 2 & 1 \\
\hline Total & $(100 \%)$ & 50 & $(100 \%)$ & 50 & 100 \\
\hline
\end{tabular}

Table 21: It is alright to talk loudly on the phone in public places

\begin{tabular}{|c|c|c|c|}
\hline $\begin{array}{l}\text { It is alright to talk loudly on the phone in public } \\
\text { places }\end{array}$ & India & USA & Total \\
\hline Strongly Disagree & $\begin{array}{ll}(66 \%) & 33 \\
\end{array}$ & $(48 \%) 24$ & 57 \\
\hline Disagree & $(10 \%) \quad 5$ & $(32 \%) 16$ & 21 \\
\hline Neutral & $(10 \%) \quad 5$ & $(4 \%) \quad 2$ & 7 \\
\hline Agree & $(4 \%)$ & $(4 \%) \quad 2$ & 4 \\
\hline Strongly Agree & $(8 \%)$ & $(6 \%) \quad 3$ & 7 \\
\hline No Answer & $(2 \%)$ & $(6 \%) \quad 3$ & 4 \\
\hline Total & $(100 \%) 50$ & $(100 \%) 50$ & 100 \\
\hline
\end{tabular}

Table 22: There should be etiquette/guidelines for mobile phone usage in public

\begin{tabular}{|c|c|c|c|}
\hline $\begin{array}{l}\text { There should be etiquette/guidelines for mobile } \\
\text { phone usage in public }\end{array}$ & India & USA & Total \\
\hline Strongly Disagree & $(10 \%) \quad 5$ & $(2 \%)$ & 6 \\
\hline Disagree & $(0 \%) \quad 0$ & $(0 \%)$ & 0 \\
\hline Neutral & $(16 \%) \quad 8$ & $(12 \%)$ & 14 \\
\hline Agree & $(28 \%) 14$ & $(20 \%) \quad 10$ & 24 \\
\hline Strongly Agree & $(44 \%) 22$ & $\begin{array}{ll}58 \%) & 29\end{array}$ & 51 \\
\hline No Answer & $(2 \%) \quad 1$ & $(8 \%)$ & 5 \\
\hline Total & $(100 \%) 50$ & $(100 \%) 50$ & 100 \\
\hline
\end{tabular}

